\title{
Diversity of Snakes in Rajegwesi Tourism Area, Meru Betiri National Park
}

\author{
Aji Dharma Raharjo*, Luchman Hakim \\ Depertement of Biology, Faculty of Mathematics and Natural Sciences, University of Brawijaya, Malang, Indonesia
}

\begin{abstract}
Rajegwesi tourism area is one of the significant tourism areas in Meru Betiri National Park, East Java, Indonesia. The area rich in term of biodiversity which are potential for developed as natural tourism attraction. The aim of this study is to identify snakes species diversity and its distribution in Rajegwesi tourism area. Field survey was done in Rajegwesi area, namely swamps forest, residential area, rice fields, agriculture area (babatan), resort area, and Plengkang cliff. This study found some snakes, encompasses Colubridae (10 species), Elapidae (four species), and Phytonidae (one species). There are Burmese Python (Python reticulatus), Red-necked Keelback (Rhabdophis subminiatus), Painted Bronzeback Snake (Dendrelaphis Pictus), Black Copper Rat Snake (Coelognathus flavolineatus), Radiated Rat Snake (C. radiatus), Striped Keelback (Xenochrophis vittatus), Checkered Keelback (X. piscator), Spotted Ground Snake (Gongyosoma balioderius), Gold-ringed Cat Snake (Boiga dendrophila), Common Wolf Snake (Lycodon capucinus), Banded Wolf snake (L. subcinctus), Cobra (Naja sputatrix), King Cobra (Ophiophagus hannah), Malayan Krait (Bungarus candidus), and Banded Krait (B. fasciatus) was found. These snake habitats distributes at 21 coordinate points.
\end{abstract}

Keywords: conservation, ecotourism, snakes.

\section{INTRODUCTION}

Snakes are legless-carnivorous reptiles living on every continent except Antarctica and can be found in aquatic, arboreal, and terestrial areas [1]. Snake habitats diversity can be influenced by geographical factors such as climate, altitude, humidity, and other micro-conditions. Snakes are valuable components to their ecology communities; playing several complex roles, included predators and prey, and has an economic value for humans. Every part of the snake usualy used by human for culinary, medicinal, pets, and other purposes. The most valuable part of snake are skin (phyton), meat, bile, and fang (cobra) [2]. Because of its value, snakes harvesting for commercial purposes become populer, so this reptile populations become endangered in their natural habitats. Deforestation and land conversion also made some snakes species were extinct [3].

Rajegwesi is one of the nature-based tourism destination areas in Meru Betiri National Park. Administratively, the park located at two regencies, Jember and Banyuwangi, East Java. Coordinated in $8.5333^{\circ} \mathrm{S}, 113.7833^{\circ} \mathrm{E}$. It spans across $580 \mathrm{~km}^{2}$ of varying topography; including sandy, coastal plains, mangrove swamps, lush rainforests, and highlands of over 1,000 m. Meru

\footnotetext{
${ }^{*}$ Correspondence address: Aji Dharma Raharjo

Email : ajidharma165@gmail.com

Address : Department of Biology, University of Brawijaya, Jl. Veteran Malang, 65145
}

Betiri National Park has several tourism areas; one of them is Rajegwesi, a coastal area. Aim of this study is to identify snakes species distribution along Rajegwesi tourism area.

\section{MATERIALS AND METHODS}

Field survey was done at Rajegwesi area of SPTN 1 Sarongan. Field survey was conducted from January to April 2014. The snake habitat survey was focused in resort area, agriculture area (babatan), swamps, rice fields, residential area, and Plengkang cliff. We used modifiedcruising methods by Branch [4] to explore and observe each of snake habitats. Each area was visited twice a day, 9-12 am and 7-11 pm (GMT $+7)$.

Direct observation was performed by using flashlight, Global Positioning System (GPS), and digital camera for documentation. We used Handbook of Visual and Field Identification of 107 Indonesian Snake [5] for identification. For additional data, interview was performed to national park officers. Questions were addressed to identify the frequencies of respondents (national park staff and local community) to found and see snake, the locations, snake types and morfology descriptions. We processed all geographic data, such as coordinate point of snake habitats, by using GIS (Geographic Information System) combine with Google Earthbased map.

Informants were interviewed (12 men and 1 woman), looking for existence of snake species. Snakes encounter location based on informant 
are Rajegwesi resort area, agricultur area (Babatan), c) swamp area, d) rice field area, e) residents area, and f) Plengkang cliff area (Figure 1). Resort area are maintained and half area used to tree nursery locations. These tree functioned to maintain the forest condition and it's used as composting training for community.

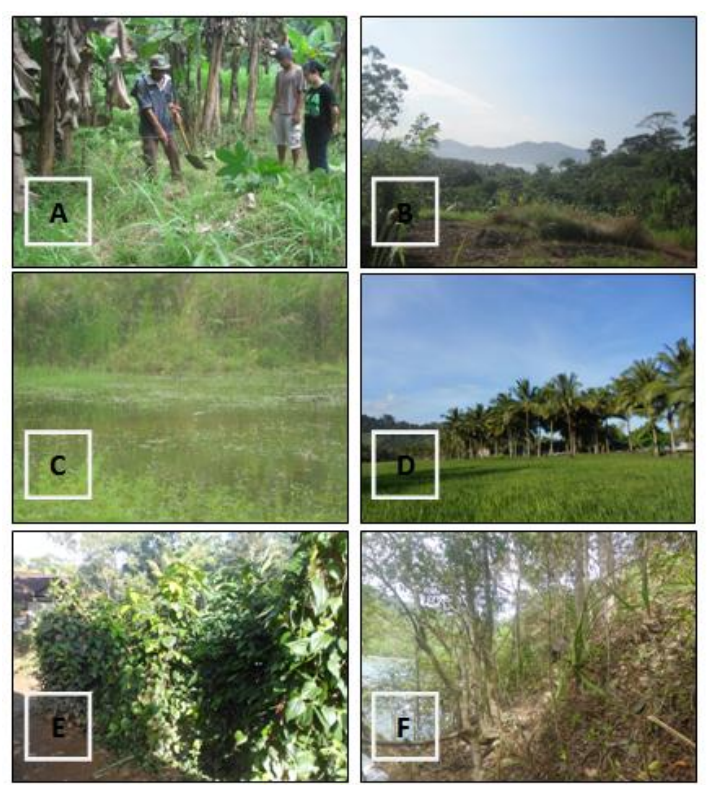

Figure 1. Snake Habitat due to Informant: a) resort area; b) agriculture area (Babatan) ; c) swamp area; d) rice field area; e) residents area; and f) Plengkang Cliff area

\section{RESULTS AND DISCUSSION}

Burmese Python found in swamp near the rice fields of human places. It also found in Plengkang cliff area, this place has a rocky ravine conditions directly adjacent to sea. According to the local community, this snake reaches $800 \mathrm{~cm}$ long size. Python reticulatus life depend on the availability of water, so often found not far from water bodies such as rivers, ponds and swamp. Python reticulatus main pray is some small mammals, birds and other reptiles such as lizards. Small snakes eat somes frogs, lizards and fish. Large snakes are reported preying on dogs, monkeys, jungle pigs, deer, including a man who 'lost' to place waiting for its prey [6].

Red-necked Keelback found in public area of rice fields and river water area overgrown with bamboo and shrubs. This species found while sunbathing on Luwingan tree. Acording to David and Vogel [7], Red-necked Keelback characteristics is chessboard color in under the scales of dorsal skins. Maximum body length reaches 130 $\mathrm{cm}$ at the North, but in parts of Sumatra only reach of $80 \mathrm{~cm}$ lenght. In generally about $60 \mathrm{~cm}$ and mature snake head colored with green stone (dark olive green) on the upper side, with yellow and red light behind to nape [5]. Painted Bronzeback Snake found in the area around Resort office and home garden. This snake characteristics is thin slender, up to about 150 $\mathrm{cm}$ long, found on hibiscus plants. Has red tounge with a long tail size, reaching a third of the total body length [7].

Gongyosoma baliodeirus has minim data species. Familiar with limb snake term. This species found in guava tree in home garden surrounded by banana plant and cotton tree. This snake has a maximum length of $50 \mathrm{~cm}$ and preys invertebrates, mainly insects and spiders [5].

Gold-ringed Cat Snake found around swamp tree and frequently found in marsh environment because it is easy to find their preys. This snake according to informants (fishermen), has $150 \mathrm{~cm}$ length size with black and yellow shade. Black Copper Rat Snake is common name of Coelognathus flavolineatusl, due to its striped color. This snake was found in coffee plant terestrial with rice fields, with $100 \mathrm{~cm}$ of length. This snake is able to sized up to $180 \mathrm{~cm}$ length and most species remain small and only reaches about $120 \mathrm{~cm}$ length. Some authors describe this species is able to grow in maximum length up to $200 \mathrm{~cm}$ [5].

Radiated Rat Snake (Coelognathus radiatus) is one species that is often encountered by the society. This snake's length up to $100 \mathrm{~cm}$, reported by informant when cleaning the livestock cage during this study. Comparing the observation to the identifications book of snakes, same style and habits of Radiated Rat Snake were agreed. These snakes are capable to living in all types of habitats to $1.500 \mathrm{~m}$ altitude and can be found at wooded areas, villages and towns [8].

Common Wolf Snake found grass field area adjacent to the rice fields and diurnal. This species can be found at residential areas, plantation areas as well as areas of lowland forest. These snakes are very agile and nimble and have a painful bite [5].

Striped Keelback snake has a small slender body and maximum body length about $50 \mathrm{~cm}$. The main character is white line parallel to the right and left in face to camouflage. Snake found in ditch paddy field. This species found in lowlands with high humidity, especially on the Java Island. This snake preys amphibians and fish [9].

Banded Wolf snake (Lycodon subcinctus) found in piles of litter and rice husk. The main character 
is slim body shape with about $80 \mathrm{~cm}$ length size. Black and white ring-shaped motif, almost same with Malayan Krait or Banded Krait and sometimes that color penetrate the stomach. This genus differentiated by size and style of the head. Spatulate head, dark brown or black, gray or white ventral. Its has short tail but slender and tapered [9].

Cobra found by informants when grassing for cattle during the study. Entong as common name, because the head shape while opening hood-like Entong when it feels threatened. The species has a medium to large body size, stocky, can reach $185 \mathrm{~cm}$ of length size, but most only about $13 \mathrm{~cm}$. The head shape larger than neck with a blunt rounded mouth and nostrils large. Eyes of medium size with round eye pupil [10].

King Cobra species found by informant at swipe area directly adjacent with Meru Betiri National Park. Identification by using Field Guide based the shape, characteristics of color and size. Communities knows it as Entong snake. Reported that almost $4.8 \mathrm{~m}$ length size and up to $12 \mathrm{~kg}$ body weight snake have been found at Singapore. Unlike most other snakes, males are longer and larger compared to females [7].

Malayan Krait was found by one of the informants at swamp area adjacent to the beach with $100 \mathrm{~cm}$ length size. Informants seen this species at swamps area among piles of dead leaves. Informants easily recognize this snake because of it's striking color and the size is fairly large. Acording to identification books this species similiar with Bungarus Candidus. They have stated slender body with about $100 \mathrm{~cm}$ length size from head to tail, and maximum length is about $155 \mathrm{~cm}$ [7].

Banded Krait found in the back yard cattle stalls owned by residents. This snake has $150 \mathrm{~cm}$ maximum length, very sensitive and prefer to stay away from humans. This snake has trianglelike bodies shaped with sharp angle on top. Striking color with black and white stripes. Black color continued to the side of abdomen. Wide head with black arrows patterns on top, and dull white mouth. Banded Krait snake hunt mainly at night (nocturnal) above the ground (terrestrial), and during the day hiding under a pile of wood or stone [7].

Results in Table 1 indicate type of snakes in the residential area, i.e. Rhabdophis subminiatus, Lycodon capucinus, Xenochrophis Piscator, Coelognathus flavolineatus, Bungarus fasciatus and Gonglyosomo balioderius. In the swamp areas: Boiga denropila, Bungarus candidus, Python reticulatus, Coelognathus radiatus, and Xenochrophis vittatus. Python reticulatus found at Plengkang Cliff. In the rice fields include Xenochrophis vittatus and X. piscator. Agriculture area (Babatan) include Naja sputatrix and Ophiophagus hannah, while in resort area we found Dendrelaphis Pictus, Gonglyosomo balioderius and $X$. piscator.

Table 1. Preference of Snake Habitat in Rajegwesi

\begin{tabular}{clc}
\hline No. & \multicolumn{1}{c}{ Habitat } & $\Sigma$ Counted Snake \\
\hline 1 & Resort area & 3 \\
2 & Agriculture area (Babatan) & 2 \\
3 & Swamp area & 2 \\
4 & Rice field area & 5 \\
5 & Residential area & 7 \\
6 & Plengkang Cliff & 2 \\
\hline
\end{tabular}

Table 2 shown 13 species in not threatened category (Least Concern), 1 spesies in evaluation (Not evaluated) and 1 susceptible species are threatened (Vulnerable). Although there are some snakes in Meru Betiri National Park classified as Least concern, its presence remains necessary to be monitored. Even somes species already vulnerable endangered, thus snake habitat in Meru Betiri areas need to be maintains and manages correctly. The snakes conservation status facilitated by national park management in managing the forests. Logging and opened agriculture needs to be monitored to minimize snakes habitat disturbance. Proper management also support Rajegwesi villages development progress and open special tours chances.

Mapping in Figure 2 is a compilation from informant and research explorations. Study area locations includes 6 points, labeled with paddy fields area, agriculture area (babatan), swamps area, resorts area, residents area and Plengkang cliff area. Distribution differences of snakes' types were related to the condition of each habitat type. Existing habitat types has its own characteristics that support needs of living snakes, either in the form of cover for protection and easy for obtaining prey. Scrub habitat has a large land closure. Habitat area of open land settlement is humid because there are sources of water. Additionally, amphibian as the prey can be found in these habitats. Abundance prey and cover vegetation, make an ideal habitat for snakes so it is easy to find [11]. Thus rapid changes in ecosystem, resulted in death or living creatures went in search of a more suitable habitat [11]. 
Table 2. Snake Family distribution in Rajegwesi area

\begin{tabular}{|c|c|c|c|c|}
\hline Family & $\Sigma$ Species & Name & Taxon & IUCN Status \\
\hline Pythonidae & 1 & Burmese Python & Python reticulatus & Least Concern \\
\hline \multirow{4}{*}{ Elapidae } & \multirow{4}{*}{4} & Cobra & Naja sputatrix & Least Concern \\
\hline & & Malayan Krait & Bungarus candidus & Least Concern \\
\hline & & Banded Krait & B. fasciatus & Least Concern \\
\hline & & King Cobra & Ophiophagus hannah & Vulnerable \\
\hline \multirow{10}{*}{ Colubridae } & \multirow{10}{*}{10} & Red-necked Keelback & Rhabdophis subminiatus & Least Concern \\
\hline & & Painted Bronzeback Snake & Dendrelaphis Pictus & Least Concern \\
\hline & & Spotted Ground Snake & Gongyosoma balioderius & Least Concern \\
\hline & & Gold-ringed Cat Snake & Boiga dendrophila & Least Concern \\
\hline & & Black Copper Rat Snake & Coelognathus flavolineatus & Least Concern \\
\hline & & Radiated Rat Snake & C. radiatus & Not Evaluated \\
\hline & & Common Wolf Snake & Lycodon capucinus & Least Concern \\
\hline & & Striped Keelback & Xenochrophis vittatus & Least Concern \\
\hline & & Checkered Keelback & X. piscator & Least Concern \\
\hline & & Banded Wolf snake & L. subcinctus & Least Concern \\
\hline
\end{tabular}

\section{CONCLUSION}

Based on biological identification, the snakes classified into three family: Colubridae (10 species), Elapidae (four species), and Phytonidae (one species). Snake habitats found in 21 coordinate points.

\section{REFERENCES}

[1] Taylor, B. and M. O'Shea. 2004. The great big books of snakes and reptiles. Hermes House Publications, London, UK.

[2] Soehartono, T. and A. Mardiastuti. 2003. Pelaksanaan Konvensi CITES di Indonesia. Jakarta: Japan International Cooperation Agency (JICA).

[3] Supriatna, J. 1995. Ular berbisa di Indonesia. PT. Bhratara Karya Aksara. Jakarta.

[4] Branch A. 2009. Cruising manual. British Columbia Goverment. Columbia.

[5] Marlon, R. 2014. Panduan visual dan identifikasi lapangan (107+ ular Indonesia). Jakarta: PT Indonesia Printer.
[6] Shine, R., Ambariyanto, P.S. Harlow, Mumpuni. 1998. Ecological traits of commercially harvested water monitors, varanus salvator, in northern sumatra. Wildlife Research 25, 437-447.

[7] David, P. and G. Vogel. 1996. The snakes of Sumatra. An annotated checklist and key with natural history. Edition Chimaira. Frankfurt, 148-149.

[8] McKay, J.L. and R. Lilley. 2012. New distributional records from the Lesser Sundas, Indonesia. Herpetological Review 43(1), 109-111.

[9] Mish, F.C. 2004. Merriam-Webster's collegiate dictionary, $11^{\text {th }}$ Edition. MerriamWebster. Springfield, Massachusetts.

[10] O'Shea, M. 2005. Venomous snakes of the world. UK: New Holland Publishers, 94.

[11] Irwan Z.D. 2007. Prinsip-prinsip ekologi ekosistem, lingkungan, dan upaya pelestariannya. Jakarta: Bumi Aksara. 